Cite as: Bouhnik, D., \& Deshen, M. (2014). WhatsApp goes to school: Mobile instant messaging between teachers and students. Journal of Information Technology Education: Research, 13, 217-231. Retrieved from http://www.jite.org/documents/Vol13/JITEv13ResearchP217-231Bouhnik0601.pdf

\title{
WhatsApp Goes to School: Mobile Instant Messaging between Teachers and Students
}

\author{
Dan Bouhnik and Mor Deshen \\ Bar-Ilan University, Ramat Gan, Israel
}

Dan.Bouhnik@biu.ac.il Mor.Deshen@biu.ac.il

\begin{abstract}
WhatsApp is a Smartphone application for instant messaging. Lately the application's popularity has risen. One of the unique features of the application is its ability to enhance communication within a group. Classroom communication between teaching faculty and high school students using WhatsApp has not yet, to our knowledge, been researched thoroughly. Therefore, we have chosen to conduct an exploratory research project employing a qualitative method. Twelve halfstructured interviews were carried out with teachers who use the application in order to communicate with their pupils.

It turns out that class WhatsApp groups are used for four main purposes: communicating with students; nurturing the social atmosphere; creating dialogue and encouraging sharing among students; and as a learning platform. The participants mentioned the technical advantages of WhatsApp, such as simple operation, low cost, availability, and immediacy. They also referred to educational advantages, such as the creation of a pleasant environment and an in-depth acquaintance with fellow students, which had a positive influence upon the manner of conversation. The participants also indicated academic advantages such as the accessibility of learning materials, teacher availability, and the continuation of learning beyond class hours. Nevertheless, there are also challenges and problems. Firstly, there is the technical difficulty that not all high school students possess a Smartphone. Secondly, teachers are apt to be annoyed by the flood of irrelevant and nonsensical messages. Also, educational difficulties may arise, such as incompatibility of language between students and the students' assumptions that their teachers should be available on a $24 / 7$ basis.
\end{abstract}

Keywords: WhatsApp, Social network, Instant message, Communication platform.

\section{Introduction}

WhatsApp is a Smartphone application that operates on nearly all current types of devices and operating systems. The application has been on the market since 2010; the declared purpose of

Material published as part of this publication, either on-line or in print, is copyrighted by the Informing Science Institute. Permission to make digital or paper copy of part or all of these works for personal or classroom use is granted without fee provided that the copies are not made or distributed for profit or commercial advantage AND that copies 1) bear this notice in full and 2) give the full citation on the first page. It is permissible to abstract these works so long as credit is given. To copy in all other cases or to republish or to post on a server or to redistribute to lists requires specific permission and payment of a fee. Contact Publisher@InformingScience.org to request redistribution permission. the developers was to replace the existing SMS platform for a system that is free of charge in an ad-free environment. As a means of sending and receiving messages to and from individuals or groups, WhatsApp includes a variety of functions, such as text messages, attached images, audio files, video files, and links to web addresses. Over the last two years, the application has become very popular, gaining over 350 million 
users and is rated the most downloaded application in 127 countries (Cohavi, 2013); everyday an average of 31 billion messages are sent (Tzuk, 2013). Technically, WhatsApp can be viewed as a social network that allows people to access a great deal of information rapidly. The simple operation scheme makes the program accessible to a variety of people of different ages and backgrounds. WhatsApp enables communication with anyone who possesses a Smartphone, has an active internet connection, and has installed the application. The overall cost of the application is very low, up to one dollar per year.

One the of the application's unique features is the option to create a group and to communicate within its boundaries. The creator of the group becomes its manager, a position that includes the privilege of adding and removing participants without the need for approval from the group members. Aside from this, all of the participants in the group enjoy equal rights. The application enables the participants to receive an alert for each message sent or, alternatively, to mute the incoming alerts for the duration of 8 hours, a day, or a whole week.

The purpose of this study is to explore classroom communication between teaching faculty and high school students using WhatsApp. As this phenomenon is relatively new and has not yet, to our knowledge, been researched thoroughly, we conducted an exploratory research. Twelve halfstructured interviews were carried out with teachers who use WhatsApp in order to communicate with their high school students. The research revealed different purposes of teachers while implementing WhatsApp with their students. While much positive influence was mentioned regarding technical, educational, and instructional issues, teachers still found themselves coping with some challenging aspects of these issues. Although the interviewees had only between six to eighteen months experience with Whatsapp as an educational tool, the findings of this research revealed an extraordinary tool that has educational and academic potential.

\section{Literature Review}

Digital communication between groups of students and between students and teachers has become popular during the last decade through various channels: Email, SMS, Facebook groups, Twitter, and recently WhatsApp. Each one of these tools has different characteristics that influence its suitability for learning purposes (Calvo, Arbiol \& Iglesias, 2014).

Previous studies examined different Instant Messaging (IM) services. One study demonstrated how high school students, who received academic support in math via IM service, were able to ask questions during the learning process after school hours. It became clear that a personal connection with the teacher was preferable to the anonymous forum; the teacher came to know the students and could help in a relevant and individually tailored manner (Hrastinski, Edman, Andersson, Kawnine, \& Soames, 2014. Another study, of university students, communicating during and after the lessons via internal SMS system that the university developed, found that students tend to ask more question and participate via IM system (Scornavacca, Huff, \& Marshall, 2009).

Usage of different platforms of Instant Messaging (IM) between faculty and class reveals the following: potential for learning enhancement (Smit, 2012); potential for learners to be active in their studies (Cifuentes \& Lents, 2011); informal communication between students (Cifuentes \& Lents,2011; Smit, 2012); in-person interaction between students and faculty related to course content and personal issues (Cifuentes \& Lents,2011); sense of belonging and community (Doering, Lewis, Veletsianos, \& Nichols-Besel, 2008; Sweeny, 2010); breakdown of teacher-student social barriers (Doering et al., 2008); and students tend to take assignments more seriously when they are public in order to impress their peers (Sweeny, 2010); Nevertheless, some teachers felt uncomfortable with the non-academic and social discourse (Doering et al. 2008); others pointed out that Instant Messaging has a negative impact on academic writing as students begin to overlook vowels and punctuation (Sweeny, 2010). 
Some teachers use Facebook-Groups in class as a learning tool. Facebook-Groups have potential for group collaboration (Fewkes \& McCabe, 2012; Wang, Woo, \& Quek, 2012), promotion of social interaction (Wang, Woo, \& Quek, 2012), promotion of interaction between students and teachers (Wang, Woo, \& Quek, 2012), and expansion of learning beyond the classroom (Fewkes \& McCabe, 2012; Wang, Woo, \& Quek, 2012). Limitations of this tool are privacy matters (Wang, Woo, \& Quek, 2012; Wang, Woo, Quek, \& Liu, 2012), students are distracted while using it for learning (Fewkes \& McCabe, 2012; Leitch \& Warren, 2011), teachers lack implementation knowledge (Fewkes \& McCabe, 2012), and the fact that the discussions are not organized (Wang, Woo, Quek, \& Liu, 2012).

Other teachers use Twitter as a microblogging tool in order to collaborate with their students. A Meta research of 21 papers on microblogging in education revealed potential for collaborative learning, sharing resources, learning any time any place, informal communication between students and between students and teachers, and enhancing students engagement. On the other hand, limitations of microblogging were mentioned, such as unfamiliarity of students with Twitter, students are not convinced of its benefits, and the length limit of text influences depth of dialog (Gao, Luo \& Zhang, 2012; Leitch \& Warren, 2011).

A comparison of the common social media and instant messaging tools in education, in a form of a smartphone application, is described in Table 1.

Analyzing previous research regarding the integration of social networks and instant massaging in education reveals that many characteristics which contribute to the learning process, such as encouraging collaborative learning, active participation in class, learning any time any place, and informal communication, are common to all the platforms. Still, research reveals that these tools aren't widely implemented.

Over the past year, the high infiltration of Smartphones into the market has initiated growing use of WhatsApp as a communication platform for various student groups, and more recently for groups of teachers and their students as well. Teachers can create a group for their students that constitutes a type of "simple social network" for the class (Fischer, 2013). A number of reasons why people adopted WhatsApp as their main communication channel rather than alternatives (such as SMS or other social networks) were listed by Church and de Oliveira (2013): the low cost of the application combined with the ability to send an unlimited number of messages, immediacy, the desire to feel a part of the trend since their acquaintances have already adopted the application, the capacity to conduct an on-going conversation with many friends simultaneously, the knitting together of a community of friends or family, and a sense of privacy relative to other social networks. That said, the users also mentioned a number of disadvantages, such as the flooding of irrelevant or nonsensical messages and the feeling that the application is not a formal channel for communication. These drawbacks lead people to use regular text messages whenever they feel the need to convey an important or unidirectional message.

Since WhatsApp is relatively a new phenomenon, little research exists regarding its influence on interpersonal communication in general, and between high school teachers and their students in particular (Church \& de Oliveira, 2013). An examination of the use of WhatsApp in a South African university class registered positive feedback from students who claimed that it was an easier way to communicate with their teachers and the rest of the class, that it was productive of fruitful discourse on relevant issues in an informal environment where students could learn intimately and authentically, and that it was also fun (Bere, 2013). Such cooperation was felt to bridge gaps in knowledge and physical distance. Overall, WhatsApp has become a shared platform that enhances accessibility, encourages cooperation, and intensifies motivation to take an active part in academic assignments (Bere, 2013; Chipunza, 2013). A study conducted among students in Spain, examined the use of WhatsApp in English language studies. The students reported a rise in 
motivation and a greater enthusiasm for reading in a foreign language (Plana et al., 2013). Still, not all responses were positive. A study conducted in Kuwait, showed a negative effect on the students' ability to develop writing skills in English as a foreign language (Salem, 2013).

Table 1: Comparison of common social media and instant messaging tools in education

\begin{tabular}{|c|c|c|c|c|c|}
\hline & Email & SMS & $\begin{array}{l}\text { Facebook } \\
\text { groups }\end{array}$ & Twitter & WhatsApp \\
\hline cost & free & payment & free & free & $\begin{array}{l}\text { Up to } 1 \$ \text { per } \\
\text { year }\end{array}$ \\
\hline accessibility & $\begin{array}{l}\text { ability to } \\
\text { change text } \\
\text { size }\end{array}$ & $\begin{array}{l}\text { ability to } \\
\text { change text } \\
\text { size }\end{array}$ & $\begin{array}{l}\text { Fixed text } \\
\text { size }\end{array}$ & $\begin{array}{l}\text { Fixed text } \\
\text { size }\end{array}$ & $\begin{array}{l}\text { ability to } \\
\text { change text } \\
\text { size }\end{array}$ \\
\hline $\begin{array}{l}\text { information about } \\
\text { user availability }\end{array}$ & $\begin{array}{l}\text { no informa- } \\
\text { tion }\end{array}$ & $\begin{array}{l}\text { no informa- } \\
\text { tion }\end{array}$ & $\begin{array}{l}\text { no informa- } \\
\text { tion }\end{array}$ & $\begin{array}{l}\text { no informa- } \\
\text { tion }\end{array}$ & $\begin{array}{l}\text { Full infor- } \\
\text { mation }\end{array}$ \\
\hline opening a group & possible & possible & easy & not natural & easy \\
\hline $\begin{array}{l}\text { adding and remov- } \\
\text { ing members to a } \\
\text { group }\end{array}$ & $\begin{array}{l}\text { Not possible } \\
\text { the App }\end{array}$ & possible & $\begin{array}{c}\text { Requires } \\
\text { participant } \\
\text { approval }\end{array}$ & $\begin{array}{l}\text { Requires } \\
\text { participant } \\
\text { approval } \\
\end{array}$ & easy \\
\hline $\begin{array}{c}\text { having a fluent } \\
\text { conversation as a } \\
\text { group }\end{array}$ & not natural & impossible & easy & not natural & easy \\
\hline privacy & $\begin{array}{l}\text { relatively } \\
\text { high }\end{array}$ & $\begin{array}{l}\text { relatively } \\
\text { high }\end{array}$ & $\begin{array}{l}\text { relatively } \\
\text { low }\end{array}$ & $\begin{array}{c}\text { relatively } \\
\text { low }\end{array}$ & $\begin{array}{l}\text { relatively } \\
\text { high }\end{array}$ \\
\hline $\begin{array}{l}\text { teachers usage in } \\
\text { private life }\end{array}$ & $\begin{array}{l}\text { relatively } \\
\text { high }\end{array}$ & $\begin{array}{l}\text { relatively } \\
\text { high }\end{array}$ & $\begin{array}{c}\text { relatively } \\
\text { low }\end{array}$ & $\begin{array}{l}\text { relatively } \\
\text { low }\end{array}$ & $\begin{array}{l}\text { relatively } \\
\text { high }\end{array}$ \\
\hline $\begin{array}{c}\text { student usage in } \\
\text { private life }\end{array}$ & $\begin{array}{l}\text { relatively } \\
\text { low }\end{array}$ & $\begin{array}{l}\text { relatively } \\
\text { high }\end{array}$ & $\begin{array}{l}\text { relatively } \\
\text { high }\end{array}$ & $\begin{array}{c}\text { relatively } \\
\text { low }\end{array}$ & $\begin{array}{l}\text { relatively } \\
\text { high }\end{array}$ \\
\hline $\begin{array}{c}\text { collaborative } \\
\text { learning }\end{array}$ & not natural & not natural & enables & enables & Enables \\
\hline sharing content & $\begin{array}{l}\text { relatively } \\
\text { easy }\end{array}$ & ungainly & $\begin{array}{c}\text { relatively } \\
\text { easy }\end{array}$ & $\begin{array}{c}\text { relatively } \\
\text { easy }\end{array}$ & $\begin{array}{l}\text { relatively } \\
\text { easy }\end{array}$ \\
\hline
\end{tabular}

WhatsApp, as a relatively new tool in education, has similar positive characteristics as previous technological tools that are implemented, but it seems that WhatsApp has some up-to-date features that encourage teacher and students to use it in order to enhance understanding, This research is conducted among high school teachers, while most of the studies mentioned above were conducted among college and university students. Although the characteristics of the different platforms and of WhatsApp as a learning tool serves different ages, our research is revealing a unique phenomenon in high-schools.

\section{Methodology}

In the present research, we worked towards a better understanding of the function of WhatsApp groups constructed for students and teachers, relevant activities, and the way that they affect both educational and academic processes were considered. Since joint class communication between students and teachers in WhatsApp groups has yet to be examined in depth, it was first necessary 
to seek out the focus of such a study and to determine the sort of research questions which needed to be asked. Therefore, we chose to conduct a pilot study in order to bridge the gaps between what we already know and what we wished to discover (Shakedi, 2012, pg. 50). We chose a qualitative method of research, including half-structured in depth interviews, aimed at a better understanding of the phenomenon and the meaning people attribute to it, rather than a quantitative scheme directed towards definitive questions and answers or the examination of specific hypotheses (Shakedi, 2012, pg. 69). The use of open questions enabled the respondents to share a variety of experiences that are unobtainable through closed end questions. They were able to tell their story in a flowing narrative that taught us a great deal about the phenomenon (Shakedi, 2012, pg. 13).

For the purpose of this study twelve half-structured in-depth interviews were conducted with teachers who used WhatsApp to communicate with the groups they taught. The interviews took the form of a friendly chat, while trying to piece together different parts of the stories into a cohesive meaning (Shakedi, 2012, pg. 72). The interviews began with a short explanation about the research, followed by a few personal background questions. Theming the interviews with the teachers was an inquiry into their motivation for opening a WhatsApp group with their students, a description of the activities in the group, including the advantages and disadvantages noted, and an examination of the insights distilled from their experiences. The information gathered throughout the interviews was not categorized in a predetermined fashion, but evolved gradually as the interviews continued. The examination proceeded as the data was collected, so an interaction took place between data collection and analysis. The collected data effected the questions we chose to ask in the next interview (Shakedi, 2012, pg. 96). Once the interviews were over and transcribed, a process of categorizing began.

\section{Research Findings}

\section{Sample of Participants}

Twelve high school teachers were interviewed, nine women and three men. Seven of them are homeroom class teachers, and five are subject-matter teachers. Homeroom class teachers usually used the application with one group, their homeroom class, while subject-matter teachers participated in a few groups ( 3 or 4). The twelve teachers, all together, handled 24 groups with more than 400 students. Six of the teachers initiated the idea of a class group, while the other responded to their students' request. Consequently, two forms of management were created: one in which the teacher managed the group and another in which students ran it. In the classes where the initiative to open the group came from the students, the teachers chose to allow the students to run it, explaining that they wanted the students to feel that it was their group and was made for them. The teacher managed different sizes of groups, depending on the structure of their schools. 
Table 2 describes the information regarding research participants.

\begin{tabular}{|c|c|c|c|c|c|c|c|}
\hline Name & Gender & Subject & $\begin{array}{l}\text { Location of } \\
\text { School }\end{array}$ & $\begin{array}{c}\text { Students } \\
\text { Socioeco- } \\
\text { nomic Level }\end{array}$ & $\begin{array}{c}\text { WhatsApp } \\
\text { Group } \\
\text { Manager }\end{array}$ & $\begin{array}{c}\text { Number of } \\
\text { WhatsApp } \\
\text { Groups }\end{array}$ & $\begin{array}{c}\text { Number } \\
\text { of Stu- } \\
\text { dents per } \\
\text { Group }\end{array}$ \\
\hline T1 & male & homeroom & central & high & teacher & 3 & $\begin{array}{l}\text { Between } \\
15 \text { to } 30 \\
\text { students }\end{array}$ \\
\hline T2 & female & sciences & central & high & student & 4 & $\begin{array}{c}\text { Less than } \\
15 \text { students }\end{array}$ \\
\hline T3 & male & homeroom & North & low & student & 1 & $\begin{array}{l}\text { More than } \\
30 \text { students }\end{array}$ \\
\hline T4 & female & English & central & high & teacher & 1 & $\begin{array}{c}\text { Less than } \\
15 \text { students }\end{array}$ \\
\hline T5 & female & homeroom & South & low & teacher & 1 & $\begin{array}{c}\text { Less than } \\
15 \text { students }\end{array}$ \\
\hline T6 & female & Sciences & North & low & teacher & 3 & $\begin{array}{l}\text { Between } \\
15 \text { to } 30 \\
\text { students }\end{array}$ \\
\hline T7 & female & Sciences & North & low & student & 3 & $\begin{array}{c}\text { Less than } \\
15 \text { students }\end{array}$ \\
\hline T8 & female & homeroom & South & low & student & 1 & $\begin{array}{c}\text { Less than } \\
15 \text { students }\end{array}$ \\
\hline T9 & female & homeroom & North & low & teacher & 1 & $\begin{array}{l}\text { Between } \\
15 \text { to } 30 \\
\text { students }\end{array}$ \\
\hline T10 & female & homeroom & central & low & teacher & 1 & $\begin{array}{c}\text { Less than } \\
15 \text { students }\end{array}$ \\
\hline T11 & female & Sciences & central & high & student & 4 & $\begin{array}{l}\text { More than } \\
30 \text { students }\end{array}$ \\
\hline T12 & male & homeroom & central & high & student & 1 & $\begin{array}{l}\text { More than } \\
30 \text { students }\end{array}$ \\
\hline
\end{tabular}

\section{Types of Communication}

Most of the communication in the examined groups was verbal, alongside some use of emoticons and images, with less use of video files. The use of the audio options and location information was almost non-existent. Still, the students utilized the possibility of changing the name of the group and the theme picture of the group repeatedly. The groups were given names such as: "The best class ever", "The genius class" or "Ms. X is in the group" (in order to remind the class that the teacher is of the group). Teachers and student used the camera frequently, in order to photograph their notebooks and sketches, to ask and to answer (see Figure 1). Teachers frequently attached URL links to learning materials. The use of emoticons is widespread by both students and teachers, while teachers and boys usually add one or two emoticons and girls frequently to add a whole line. 


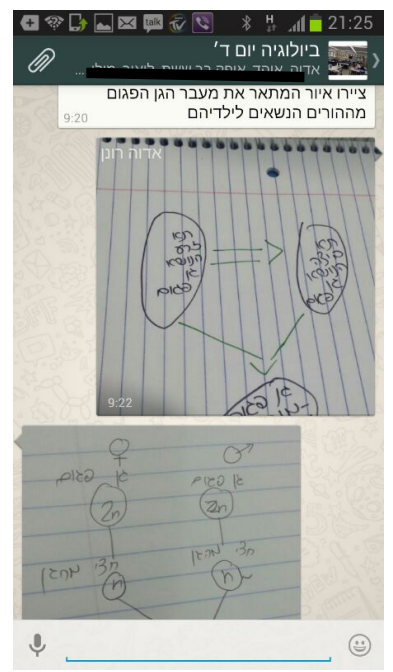

Uploaded sketches from students notebooks

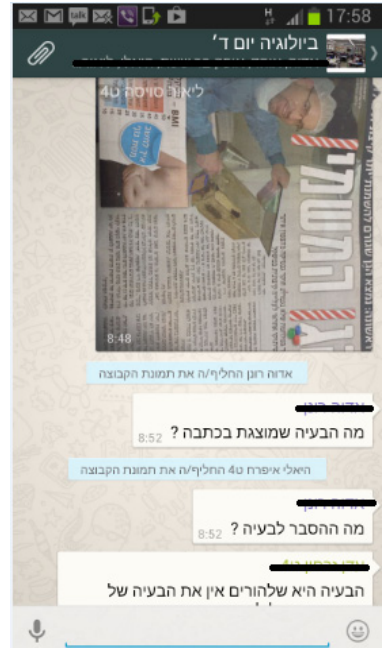

Teacher uploaded relevant newspaper article

Figure 1: Examples of communication

\section{The Group's Purpose}

Four main goals motivating the creation of a WhatsApp group were mentioned repeatedly by the teachers interviewed.

\section{Objective I}

Communicating with the students, sending information, managing the class, and helping students to feel up to date: Using WhatsApp groups to communicate saves a lot of time that otherwise would be spent trying to send the message through other means and increases class efficiency by reminding students what they need to bring and where everything occurs.

\section{Objective II}

Grooming a positive social atmosphere, whether or not in a homeroom class, in order to cultivate a sense of belonging and community through the WhatsApp groups.

\section{Objective III}

Creating a dialogue between the students to enable them to share information and work as a team. These things occur when students begin to help each other, answer each other's questions, and share their discoveries.

\section{Objective IV}

Using the groups as a learning platform in order to improve the accessibility of learning materials and the performance of learning activities.

Most of the teachers began with only one objective in mind and over time discovered other advantages. For instance, T4, an English teacher, who created the group as a learning platform for the practice of writing, realized that the group had a social aspect when students began posting personal observations from a trip. T2, a Biology teacher, initially created the group so that she could communicate with her students. She felt that by the end of the school year students tend to 
"become lost" because continuity gets interrupted by final exams and other events which cause classes to be canceled. She then discovered that the group remained active even after the school year ended and had become a support group for the graduates. T1, a homeroom class teacher, created the group for practical reasons, such as organizing and forwarding announcements. However, he soon discovered that the WhatsApp group had a positive influence on the social atmosphere of his class and became a source of enjoyment for the students.

Homeroom teachers usually started the group with communication with students in mind, while subject-matters teacher started with the expectation of using the group as a learning platform. Creating dialog and sharing between students were not planned by most teachers and were developed as the group evolved. We did not reveal any pattern regarding the purpose of establishing the WhatsApp groups, not with gender, nor with location of school, student socioeconomic level, or with group managing.

Table 3 describes the teachers' original purposes of establishing WhatsApp Groups with their Students.

Table 3: Purpose of Teachers in Establishing WhatsApp Group with their Students

\begin{tabular}{|c|c|c|c|c|}
\hline Name & $\begin{array}{l}\text { Communication } \\
\text { with Students }\end{array}$ & $\begin{array}{c}\text { Grooming } \\
\text { Positive } \\
\text { Social } \\
\text { Atmosphere }\end{array}$ & $\begin{array}{c}\text { Creating } \\
\text { Dialogue and } \\
\text { Sharing }\end{array}$ & $\begin{array}{l}\text { Learning } \\
\text { Platform }\end{array}$ \\
\hline T1 & Main goal & Side effect & & \\
\hline T2 & & & Side effect & Main goal \\
\hline T3 & & Main goal & & \\
\hline T4 & & & Side effect & Main goal \\
\hline T5 & Main goal & Main goal & & \\
\hline T6 & & Side effect & Side effect & Main goal \\
\hline T7 & Main goal & & & Main goal \\
\hline T8 & Main goal & Main goal & & \\
\hline T9 & Main goal & Main goal & & \\
\hline T10 & Side effect & Side effect & Main goal & Main goal \\
\hline T11 & Main goal & Side effect & Side effect & \\
\hline T12 & Main goal & & Side effect & Side effect \\
\hline
\end{tabular}

The participants described both advantages and challenges involved in using WhatsApp with students. These were categorized into three types of issues: technical, educational and academic (Figure 2). 


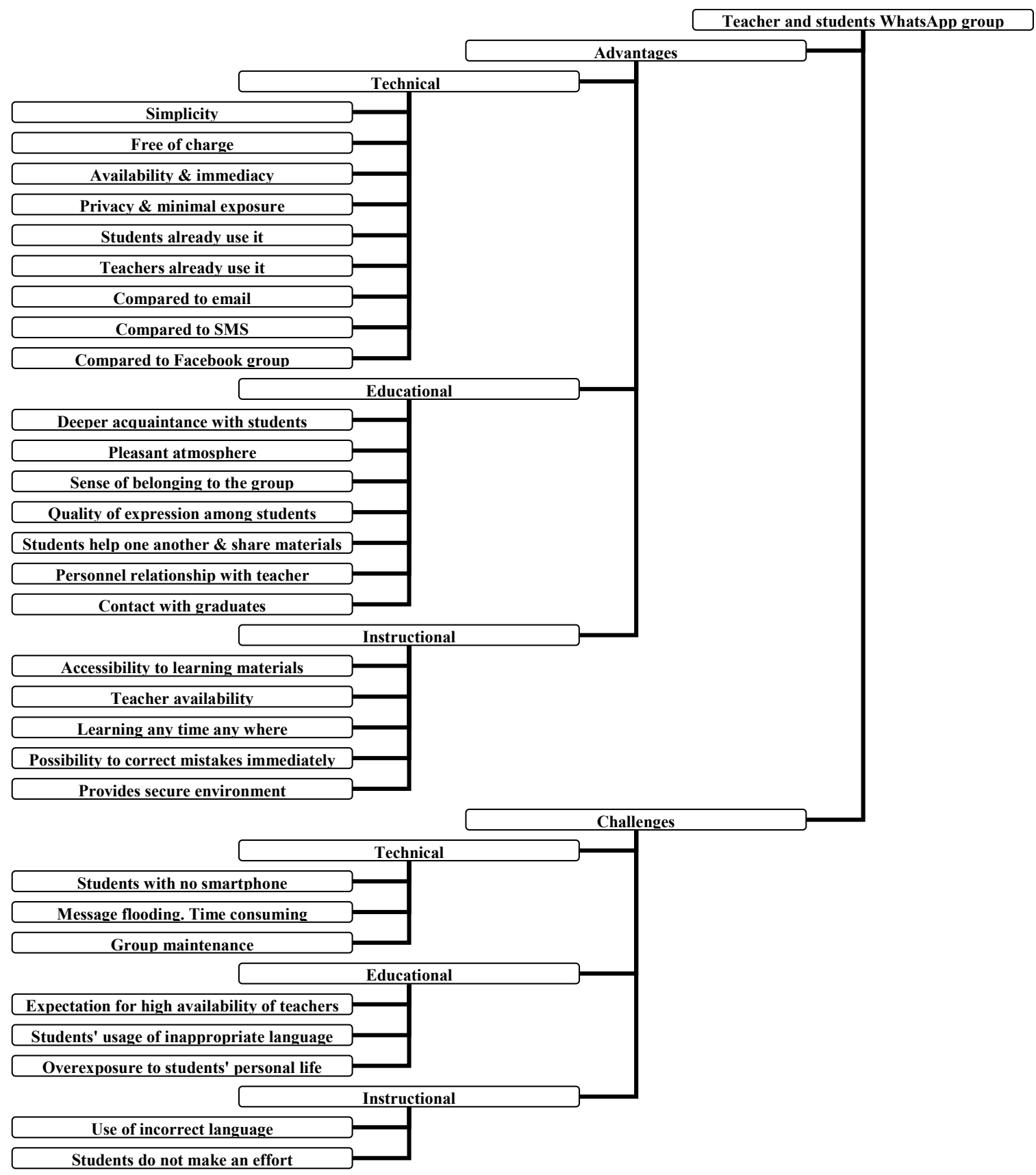

Figure 2: Categorization of findings

\section{Technical Advantages}

One of the main benefits of WhatsApp is its simplicity. The respondents named a variety of technical advantages of this tool. All the participants had experienced disappointment in their previous attempts at incorporating various technologies into their educational processes. WhatsApp's simplicity, low cost (if any), privacy (in comparison to other social networks like Facebook or Twitter), and widespread use among teachers and students alike in their private life made it a prime choice. 
Most of the participants still use email but have experienced low compliance, due to the fact that many students do not check their email on a daily basis, which makes communication less effective. Some of the participants also use SMS as a form of interpersonal communication with students, but the cost is higher and it does not facilitate communication within groups. T3 said, "I used to send SMS greetings on students birthdays and holidays. Each student received his or her own greeting, but I was working hard on it, and the communication was only between me and the student. Now it's a whole different thing."

The three respondents who reported managing a Facebook group for their class claimed that there were more drawbacks than benefits. T6, a physics teacher said, "I tried working with the class using a Facebook group; it didn't go very well. The students didn't like it and neither did I; it

wasn't as prompt and students weren't up-to-date. Students are also less active on Facebook these days; they feel quite exposed since the grownups joined." T3 added, "In the past, my students asked me to open a group in Facebook. I used to upload announcements and relevant content. Taking care of this group demanded a lot of efforts from me. For me, Facebook wasn't as fluent as WhatsApp. Furthermore, students from other classes and even from other schools, asked me to be their Facebook friend. If I didn't approve, some of the girls felt offended. Then, I decided to stop being active in Facebook. I prefer the privacy and simplicity of WhatsApp rather than Facebook."

In conclusion, the interviews showed that WhatsApp is preferable to the other means of communication and social networks tested by the teachers.

\section{Educational Advantages}

The respondents expressed as a clear benefit the ability to get to know the students in-depth. T8 said, "I learn a lot about my students, what bothers them, what helps them, what are the areas in which they excel... who responds aggressively and who's balanced; it helped me to get to know them better." The group also contributes to a positive atmosphere in the class. T1 said, "The group became so much fun, students upload funny things... and I upload personal things as well... it creates a fun feeling with the class." T2 added, "One of the groups that I started to teach started the year with students who didn't have anything in common and many social conflicts. Establishing a WhatsApp group and encouraging the group to take part in it, contributed to the positive atmosphere in that class." T8 continued, "The students need it; the group gave them a sense of belonging. They want to be part of the group." T7 added, "A student that left the class, asked to stay part of the group, and even participated in the conversation from time to time. He said that he still wants to be part of the group although he doesn't study with them any more." It seems that belonging to a WhatsApp group reinforced the student's connection to the class.

The teacher's presence in those groups seemed to have a positive influence on the manner of conversation. Teachers reported a restrained manner, probably due to their presence, that expressed itself when students would admonish someone for being rude. T4 told us that, "Once, one of the students wrote rude words to another one. I used my ability as the group-manager and without any warning removed him from the group. He wrote to me privately, apologizing of his behavior. It was very important for him to stay part of the group. The rest of the class understood the message, it didn't happen again." Teachers described that, often, when a student wrote rude words, other students asked him or her to behave. Some teacher felt that this was a result of the fact that they were part of the group, while others felt, that sometimes, students forgot that the teacher was part of the group and expressed themselves in a non-formal manner.

T5 added, "Some of the students don't have a lot of people to talk to, so the group became a substitute, where they shared experiences and asked for advice, and that carried on into the summer vacation." Sometimes teachers were the ones to encourage the students to share information and 
help each other. For others it came naturally. T2: "The students began sharing summaries of lessons, helping each other with different questions, and they do it amazingly." T7: "Sometimes students would answer each other's questions, especially if I wasn't available and an exam was coming up or homework was due. I later encouraged them to continue." T11 added, "Even when students ask me something directly, usually one of the students answers before I get a chance."

WhatsApp can contribute to the interpersonal relationship between teacher and students. Students feel more comfortable about approaching their teachers. T6 said that "even though I started off the year by telling them they can approach me anytime, they hesitated to call. With WhatsApp they feel free." T7 added, "Before we had the WhatsApp group, students didn't feel comfortable to call me; they said that they don't want to bother me. Then, they started to write to me privately in WhatsApp - they felt comfortable to write any time, any question. When I realized that I was answering the same question repeatedly, I opened the WhatsApp group. Still, many students continue to ask me questions privately, I think that they feel that they can talk to me more freely this way."

T2: "Sometimes a student is stressed out and needs emotional assistance rather then academic aid. In that case, I approach him with a personal message and find out what's wrong."

An interesting phenomenon is the continuance of the groups beyond the school year. Two of the teachers had a senior class that kept the group going: one of the classes was homeroom and the other was subject matter. T2 revealed, "As the end of the school year approached and the final exams were concluded, I told the students that they can delete the group. They refused to do so and used it to keep in touch; they still send updates and links to articles or images that had to do with what we studied."

\section{Academic Advantages}

WhatsApp enables easy and quick transference of links to study materials, unlike any other technologies--which often don't work--or other forms of communication that students just don't use after school hours. Sending study materials through WhatsApp ensures that everyone gets the message, whether it's a video intended for class or a copy of a solution for an exercise sent after school hours.

The high availability of teachers to the students' questions can potentially enhance the learning process. T7 described, "Students use the group to ask me questions quite a lot". T6 reported, "When I have WhatsApp groups for my classes I feel available. As a subject teacher I'm not in school everyday, so that's very important."

WhatsApp enables learning beyond the classroom's borders. T6 responded, "More often than not, a discussion arises about the homework I assigned or a report that's due. When the discussion occurs I try to keep quiet and let them handle it." T2 described, "We're doing a Bio-research. The students document the experiment through WhatsApp; they film the different stages and upload it for the entire group to see." T10 added that her students came from difficult backgrounds and rarely did their homework. Since she created the group she uploaded a riddle or a question every evening and the students showed a lot of interest. It was the first time these students got to go over the material again at home and return to the classroom with additional knowledge. T12 said that when he started sending a question the evening before an exam, the students began asking for more questions and were very active. The ability to correct students' mistakes immediately is very significant. T4, an English teacher, corrects spelling and grammar mistakes as soon as they occur. Other teachers also reported that they comment gently and immediately, so the mistake won't strike roots. 
The teachers feel that their presence gives the students a sense of security: they have someone of whom they can ask questions, they don't feel alone. Even the shy students can see other student's questions and enjoy the answers shared with everyone.

\section{Technical Challenges}

The main technical challenge is the fact that not all students possess a Smartphone or the application. If a class has such students, and they are very few (no more then two per class), the teachers are obligated to be sensitive and to keep up the connection with those students through other means, usually by simple text messages.

Some teachers reported being swamped by too many messages, in a way that burdened and annoyed them, especially if they have more than one group or groups that are bigger than $15 \mathrm{stu}-$ dents. Other teachers were bothered by the late hours in which the messages were sent. However, the teachers were also able to suggest solutions to these problems. For example, some teachers choose to mute the alert signal and to choose when to read the messages and when to respond. In that way, the group did not become a burden.

\section{Educational Challenges}

Beyond the students' high expectations of teacher availability, the teachers are also faced with other educational dilemmas. They are exposed to the personal lives of their students firsthand, and find themselves witnessing conversations that are not compatible with the educational path the school is trying to promote. T5, for example, chose to remove a student from the group because he spoke to another student in unpleasant manner. T7 decided to leave the group because the general direction of the conversations was not to her liking; she came back only when the students promised to behave. These ongoing firsthand encounters with the students raised new educational dilemmas for teachers. Interestingly, T11 reported she did not need to deal with such issues, because her students would admonish each other when necessary. She attributed their behavior as due to her presence in the group.

\section{Academic Challenges}

Since students tend to use less formal language--frequently slang--even when the subject at hand is academic, teachers can feel challenged by their students' manner of expression. In formal notebook or assignment writing, teachers tend to correct mistakes or inappropriate phrase choices. Use of the digital application has led the teachers to ponder the issue of whether to correct and how often. Another academic challenge is caused by the teachers' availability, leading the students to demand a "here and now" solution. This does not encourage them to postpone immediate gratification by attempting to deal first with the task by themselves. .

\section{Conclusion}

The in-depth interviews conducted in this experiment with teachers who use WhatsApp to communicate with their classes as a part of their teaching process, raise a variety of educational and pedagogical issues and suggest some practical methods of implementation. The WhatsApp's groups examined were oriented to at least four goals: communicating with students, grooming a positive atmosphere and a sense of belonging in the class, creating a dialogue, using and sharing a learning platform. All of the teachers, at the start, thought about implementing one or two goals, but over time discovered that groups fulfilled other purposes as well. Teachers were not aware of other goals of using WhatsApp, rather than their own. They did not share their experience with other teachers; each one of them thought that they were the one who was working with WhatsApp. As researchers, we gained a lot of knowledge and new insights just by listening to the 
teachers; therefore, the conclusion of this study is that it is worthwhile to find a way to establish a dialogue between teachers, so that they can exchange ideas and suggestions about how to deal with the challenges and to broaden their understanding of the ways the application can implement the school's educational and pedagogical goals. We encouraged these teachers to participate in a WhatsApp group that we opened specifically for this purpose.

It appears that it is actually the technical benefits that are opening the path for the introduction of WhatsApp into the classrooms. As of today, it seems that WhatsApp has advantages over other technological tools employed by the education system, such as low cost, simplicity, accessibility, efficiency, and natural language (Church \& De Oliveira, 2013). Until recently there was no technological tool which was used naturally by adults and students alike. Email was more comfortable for the teachers than for the students. Students felt at home in Facebook groups, but teachers tended to visit them less and then exclusively for the purposes of the class group. WhatsApp application has crossed the dividing lines. Both teachers and students use it in their daily lives, so this technology facilitates communication between them. For many years, we were trying to teach the teachers many kinds of educational technologies, which administrators thought could contribute to schools (Cuban \& Cuban, 2009, p. 19). WhatsApp might be the first technology that entered the class without any training or administrator supervision, as teachers and students are using it in their private life, and its advantages enabled it to be become, naturally, an educational technology.

Some teachers claim that the fact that not all students have access to the application is temporary, since the number of students with Smartphones increases daily. Most of the teachers who participated in this research came from schools located in areas of low socio-economic status. Nevertheless, the use of Smartphones is widespread even among such students.

Examining the educational aspect of WhatsApp has demonstrated a variety of benefits. The open style discussion enables the teachers to get to know their students in depth and to create a positive atmosphere as well as a sense of belonging. However, challenges, such as the demand for constant availability, foul language and behavior and the witnessing the students' private world, may cause adults to feel uncomfortable. It is also worth taking into account that operating such a group requires the teachers to invest time beyond their regular work hours, in addition to being swamped with messages. These issues require attention and special tools to help teachers cope, to feel more comfortable, and to become more efficient and less burdened. Partial solutions have already been found. Many teachers felt that their presence in the groups had a positive affect on the students. Whether the teachers were dominant or quiet listeners, the students were aware of their presence and behaved accordingly in respect to style of writing, the way they treated each other, and the way they expressed themselves in relation to the content learned. It is worthwhile to conduct further research that examines the students' opinions regarding the teachers' influence on the manner in which they converse.

As of now, it is possible to say that WhatsApp enables students to co-operate and work as a team, an essential skill in the $21^{\text {st }}$ century, which is not fully developed in the traditional class. The dialogue between students, whether spontaneous or directed by the teachers, creates an atmosphere of cooperation, solidarity, and coming together to solve problems and deal with challenges. There seems to be a real potential here to better promote these skills. It is time to plan for activities that further the use of these skills and then to examine thoroughly whether a WhatsApp group can contribute to their development.

Academically speaking, a variety of advantages -- accessibility of learning materials, the possibility of learning any time and any place in a secure milieu -- exist alongside difficulties such as improper use of language and reliance on the teachers' help without trying hard enough independently. The ability to access information, content, support, and personal aid on a regular basis, re- 
gardless of the physical presence of a student in class, potentially can enhance the learning process. Such options appear to be of especial significance for students who come from an unnurturing environment and need encouragement and someone to whom they may direct their questions (Chipunza, 2013). The interviews demonstrated both benefits and drawbacks from the teachers' points of view. It is imperative to examine the student's view as well and to increase the available data on this subject.

If WhatsApp becomes a common tool for teachers and students in the classroom, there will be need for further research in order to identify user properties and the best way to integrate them into educational and pedagogical goals. This will necessitate the implementation of a wide range of qualitative research methodology. Such research will inevitably yield both theoretical and practical conclusions. The interviews in this study dealt with high school students; further research should examine junior high and elementary schools and universities as well.

\section{References}

Bere, A. (2013). Using mobile instant messaging to leverage learner participation and transform pedagogy at a South African University of Technology. British Journal of Educational Technology, 44(4), 544561.

Calvo, R., Arbiol, A., \& Iglesias, A. (2014). Are all chats suitable for learning purposes? A study of the required characteristics. Procedia Computer Science, 27, 251-260.

Chipunza, P. R. C. (2013). Using mobile devices to leverage student access to collaboratively-generated resources: A case of WhatsApp instant messaging at a South African University. International Conference on Advanced Information and Communication Technology for Education (ICAICTE 2013).

Church, K., \& de Oliveira, R. (2013). What's up with whatsapp? Comparing mobile instant messaging behaviors with traditional SMS. Proceedings of the 15th International Conference on Human-computer Interaction with Mobile Devices and Services (pp. 352-361). ACM.

Cifuentes, O. E., \& Lents, N. H. (2011). Increasing student-teacher interactions at an urban commuter campus through instant messaging and online office hours. Electronic Journal of Science Education, 14(1).

Cohavi, A. (2013). How did Whatsapp became the strongest social network? Calcalist. Retrieved from http://www.calcalist.co.il/local/articles/0,7340,L-3593840,00.html

Cuban, L., \& Cuban, L. (2009). Oversold and underused: Computers in the classroom. Harvard University Press.

Doering, A., Lewis, C., Veletsianos, G., \& Nichols-Besel, K. (2008). Preservice teachers' perceptions of instant messaging in two educational contexts. Journal of Computing in Teacher Education, 25(1), 512.

Fewkes, A. M., \& McCabe, M. (2012). Facebook: Learning tool or distraction? Journal of Digital Learning in Teacher Education, 28(3), 92-98.

Fischer, Y. (2013). "The Facebook is dead - long live WhatsApp". De Marker. Retrieved September 26, 2013, from http://www.themarker.com/technation/1.2126492

Gao, F., Luo, T., \& Zhang, K. (2012). Tweeting for learning: A critical analysis of research on microblogging in education published in 2008-2011. British Journal of Educational Technology, 43(5), 783-801.

Hrastinski, S., Edman, A., Andersson, F., Kawnine, T., \& Soames, C. A. (2014). Informal math coaching by instant messaging: Two case studies of how university students coach K-12 students. Interactive Learning Environments, 22(1), 84-96.

Leitch, S., \& Warren, M. J. (2011). Social networking and teaching: An Australian case study. In InSITE 2011: Proceedings of Informing Science \& IT Education Conference (pp. 315-326). Informing Science Institute. 
Plana, M. G. C., Escofet, M. I. G., Figueras, I. T., Gimeno, A., Appel, C., \& Hopkins, J. (2013). Improving learners' reading skills through instant short messages: A sample study using WhatsApp. 4th WorldCALL Conference, Glasgow, 10-13 July 2013.

Salem, A. A. M.(2013). The impact of technology (BBM and WhatsApp applications) on English linguistics in Kuwait. International Journal of Applied Linguistics \& English Literature, 2(4), 64-69.

Scornavacca, E., Huff, S., \& Marshall, S. (2009). Mobile phones in the classroom: If you can't beat them, join them. Communications of the ACM, 52(4), 142-146.

Shakedi, A. (2012). Words which try to touch - a qualitative research - theory and practice (8th printing). [in Hebrew] The University of Tel Aviv. Tel Aviv: Ramot Publication.

Smit, I. (2012). WhatsApp with BlackBerry; Can Messengers (BBM) be MXit?. In Proceedings of the 14th Annual Conference on World Wide Web Applications. Cape Peninsula University of Technology, Cape Town, South Africa.

Sweeny, S. M. (2010). Writing for the instant messaging and text messaging generation: Using new literacies to support writing instruction. Journal of Adolescent \& Adult Literacy, 54(2), 121-130.

Tzuk, A. (2013). Whatsapp has 350 million active users a month. [in Hebrew] Calcalist. Retrieved October 23, 2013 from http://www.calcalist.co.il/internet/articles/0,7340,L-3615097,00.html

Wang, Q., Woo, H. L., \& Quek, C. L. (2012). Exploring the affordances of Facebook for teaching and learning. International Review of Contemporary Learning Research, 1(1), 23-31.

Wang, Q., Woo, H. L., Quek, C. L., Yang, Y., \& Liu, M. (2012). Using the Facebook group as a learning management system: An exploratory study. British Journal of Educational Technology, 43(3), 428438.

\section{Biographies}

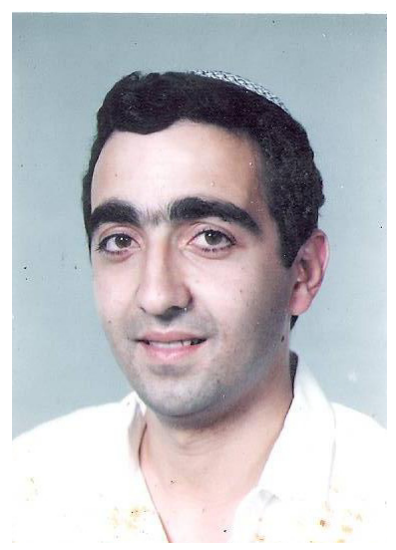

Dr. Dan Bouhnik is a faculty member in the Information Science department in Bar Ilan University (BIU) and in the Computer Science department in Lev Academic Center (LAC) in Israel. He is the author of a number of books used for teaching Advanced Computer Sciences and his professional interests include virtual learning and its effect on the thinking process, information needs of special groups as well as the infusion of new technologies in the learning environment.

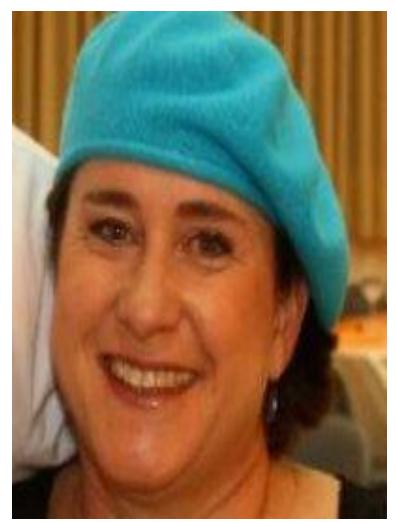

Dr. Mor Deshen has a master's degree in education from Liverpool University and a Ph.D. in Information Sciences from Bar Ilan University. She is currently teaching in Bar-Ilan University. She also completed a two-year program in Educational Leadership at the Mandel School in Jerusalem.

Dr. Deshen served as AMIT Educational Network's head of Pedagogical Department and as Deputy Director of R\&D and Assessment. 